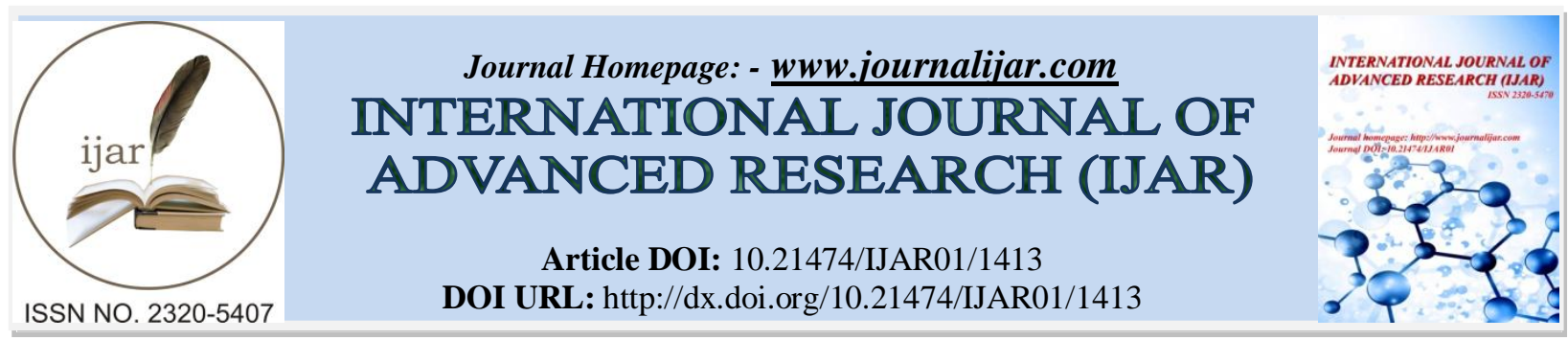

RESEARCH ARTICLE

\title{
LITHOLOGY AND FOREST IN THE SOUTH-EAST DRY AGRO-CLIMATIC ZONES OF KARNATAKA USING REMOTE SENSING AND GIS TECHNIQUES.
}

Jagadeesha Menappa Kattimani* and T.J.Renuka Prasad.

Research Scholar and Professor, Department of Geology, Jnana Bharati Campus, Bangalore University, Bangalore560056.

\section{Manuscript Info}

Manuscript History

Received: 12 June 2016

Final Accepted: 19 July 2016

Published: August 2016

Key words:-

Closepet Granite, Basalt, Lithology,

Hard rock terrain and Forest.

\section{Abstract}

The Closepet granites are a major geological feature of this region and are from the Lower Proterozoic era. This belt of rocks extend in the north-south direction in $50 \mathrm{~km}$ belt. The different types of geology in the study area which includes Bababudan, Chornakite, Gneisses, Granites , Laterites and Schistose rocks. In the study area, granites are dominant (1062sq km), Gneissic rocks occurred (950 sq km ),schistose rocks (772sq km),chornakite is $475 \mathrm{sq} \mathrm{km}$, Bababudan about $72 \mathrm{sq}$ $\mathrm{km}$. The areal extent of different litho units also listed. In the Forest area wise Granite $2340 \mathrm{sq} \mathrm{km} \mathrm{(71 \% ),} \mathrm{Metabasalt} 348$ sqkm (10\%), Schist 343 sqkm (10\%), Charnockite 81 sq km (2\%), Sillimanite 65 sqkm (1\%), Conglomerates 37\% (1\%) Limestone 37 Sqkm (1\%), Laterites $20 \mathrm{sq} \mathrm{km}$, Gneiss $11 \mathrm{sqkm}$, Rhyolite $4 \mathrm{sq} \mathrm{km}$, and Dykes 3 sqkm.

\section{Introduction:-}

Forests and water are intrinsically intertwined as forested watersheds have significantly different behaviour from non-forested watersheds as the former is more helpful in infiltration of rainfall. The nature of vegetation in the catchment is important in ground water recharge, runoff and soil moisture conditions, soil erosion and soil quality (Biao et al. 2010; Bruijnzeel 2004). Despite the fact that the forest-water relationship is not all that simplistic, being an outcome of many factors of climatic, edaphic, geological and biological nature, the importance of forests in water conservation has been accepted globally (Bradshaw et al. 2007; Makarieva et al. 2006).

In South India, the huge Late Archaean Closepet batholith provides an unusual opportunity to study the emplacement of granitic magmas at different crustal levels, since it crops out along a natural crustal section spanning 10-13 km in depth, from granulitic lower crust in the South to greenschist-facies upper crust in the North. Due to its elongate shape, the main body of the Closepet batholith has been suggested to be syntectonically emplaced during strike-slip tectonics by Drury et al., 1984 and Jayananda and Mahabaleswar, 1991. Nevertheless, northern cogenetic intrusions display more isotropic shapes without obvious magmatic

The forest cover is broadly classified in 4 classes, namely very dense forest, moderately dense forest, open forest and mangrove. The classification of the cover into dense and open forests is based on internationally adopted norms of classification. It has not been possible to further segregate the dense forest into more classes owing to enormity of 
work of ground validation and limitations of methodology. Mangroves have been separately classified because of their characteristic tone and texture and unique ecological functions. The other classes include scrub and non-forest. These classes are defined is below.

\begin{tabular}{|c|c|}
\hline Very dense Forest & $\begin{array}{l}\text { All Lands with tree cover (Including mangrove cover) of canopy density of } 70 \% \text { and } \\
\text { above }\end{array}$ \\
\hline Mod Dense forest & $\begin{array}{l}\text { All lands with tree cover (Including mangrove cover) of canopy density between } 40 \% \text { and } \\
70 \% \text { above }\end{array}$ \\
\hline Open forest & $\begin{array}{l}\text { All lands with tree cover (Including mangrove cover) of canopy density between } 10 \% \text { and } \\
40 \%\end{array}$ \\
\hline Scurb & $\begin{array}{l}\text { All forest lands with poor tree growth mainly of small or stunted trees having canopy } \\
\text { density less than } 10 \text { percent }\end{array}$ \\
\hline Non Forest & Any area not included in the above classes \\
\hline
\end{tabular}

\section{Location Map:-}

Source: Forest Survey of India

\section{Location of the Study area:-}

The study area is forest within the Dry Agro Climatic Region of Karnataka and spreads over in 3294 sqkm. It lies between $12^{\circ} 30^{\prime} 0^{\prime \prime}$ and $15^{\circ} 0^{\prime} 0^{\prime \prime}$ latitude and between $75^{\circ} 30^{\prime} 0^{\prime \prime}$ and $78^{\circ} 30^{\prime} 0^{\prime \prime}$ longitude and it encompasses seven districts viz., Bangalore Urban, Bangalore Rural, Ramanagara Tumkur, Kolar, Chikkaballapura, Chitradurga. Total district area is $35214 \mathrm{sqkm}$ and the forest area which is focus of the study is only 9\% (Map 1.1).

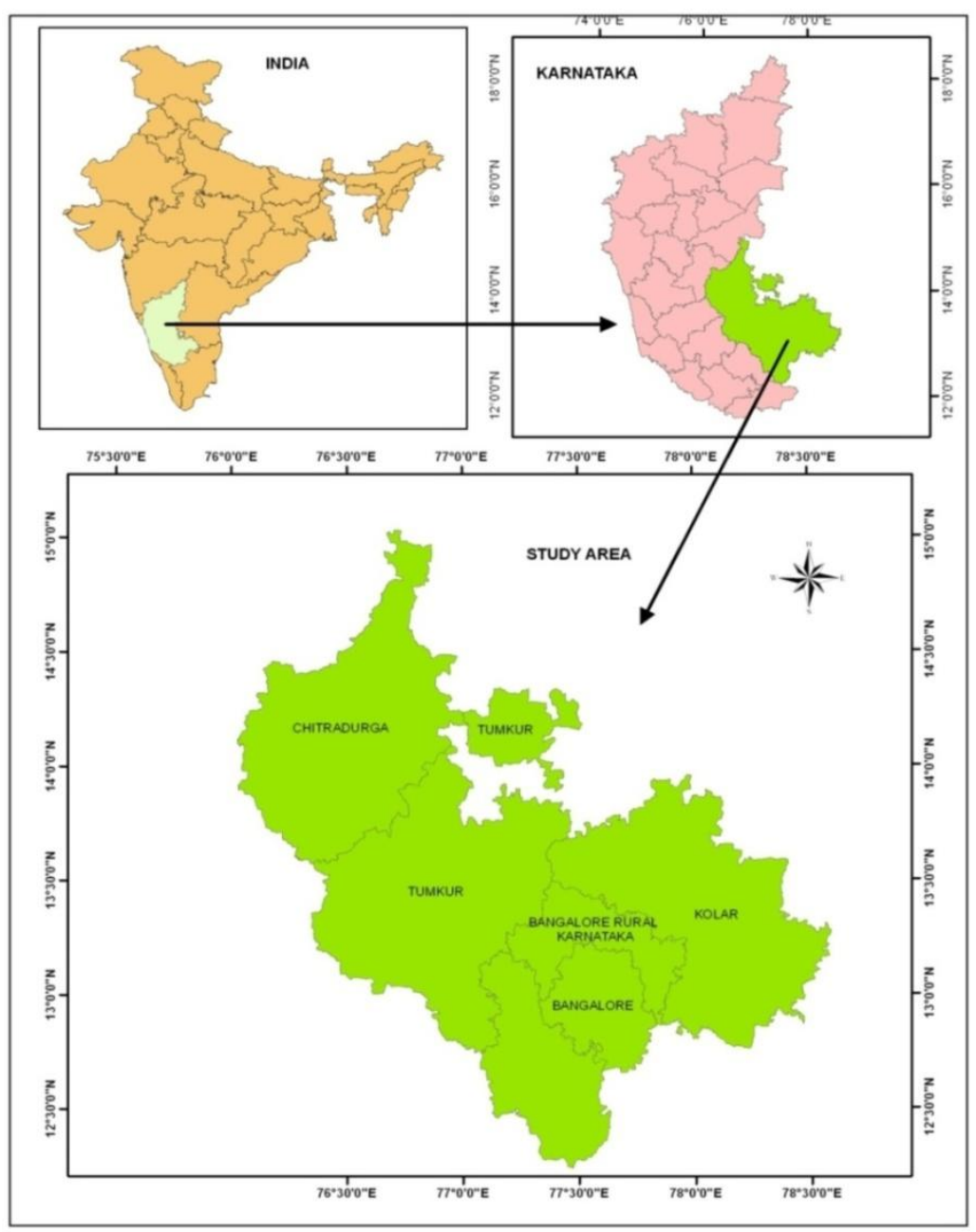

Map 1.1:- Location Map of the study area. 


\section{Methodology:-}

The South-East Agroclimatic zone of Karnataka data were colleted from the Karnataka state Remote sensing application centre . Creating different thematic maps of lithological features in the selected area using Remote Sensing and GIS Techniques. Arc GIS version 10.2.1 very useful tool to generating different Lithological maps of Agroclimatc zones of Karntaka. Used 1:50,000 scale toposheet for referenced purpose.

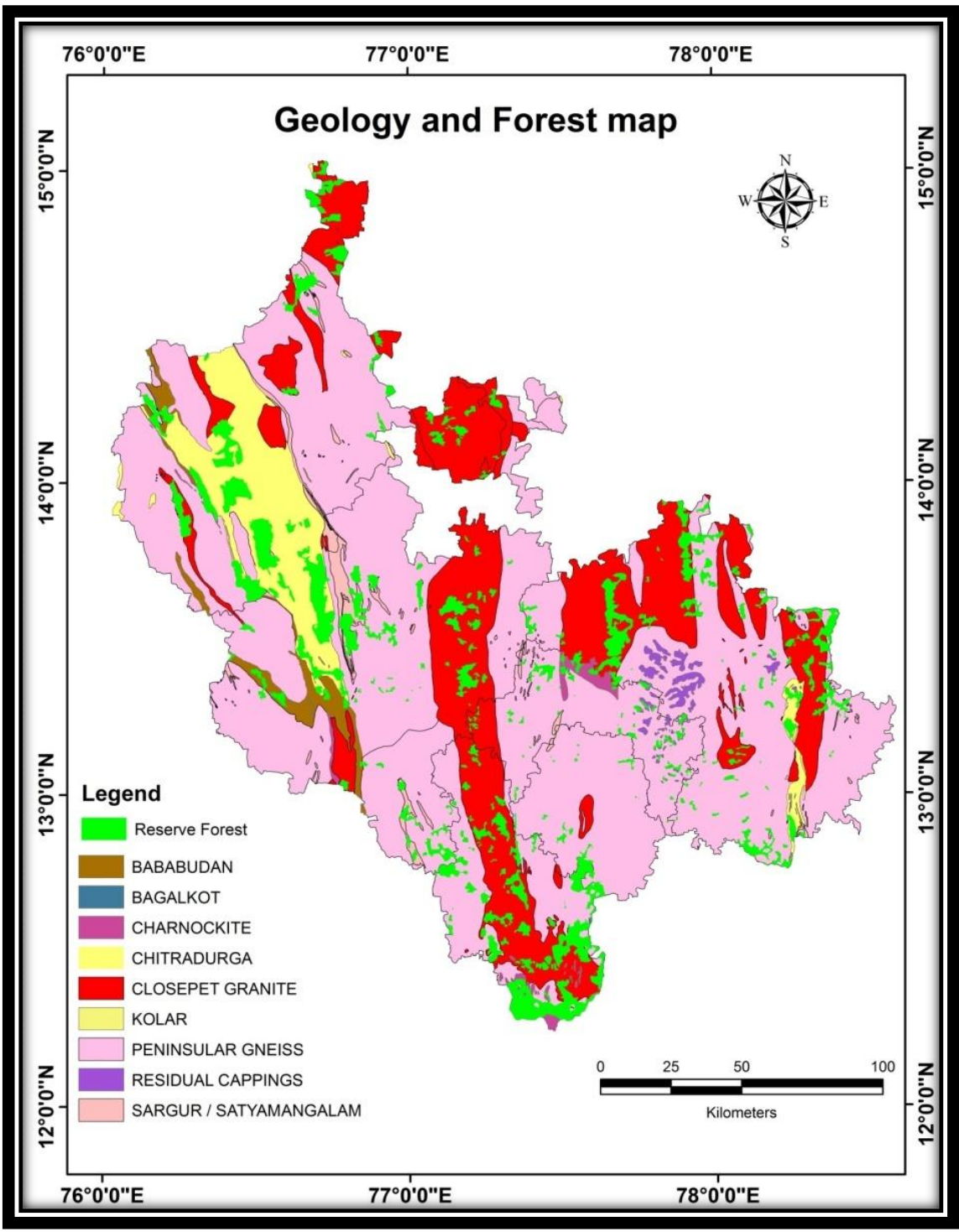

\section{Results:-}

Map 1.2:- Forest and Geology Map.

The chief rock types occurring in Bangalore Urban district are granites and gneisses that are highly jointed. The sheet joining parallel to the exposed surface is a particular characteristic of Bangalore gneisses. Granite and gneisses are intruded by a number of basic dykes. Dykes are oriented East-West as well as North-South. Lateritic capping is confined to higher elevations such as White Field and Ramagondahalli. Bangalore Rural district forms part of the Deccan plateau and is covered by peninsular gneissic complex, basic dykes and laterites. Granites occurring in gneissic complex vary in colour, texture and structure.

The rock formations of Tumkur district belongs to Archaean complex and mainly consists of crystalline schists. the granitic gneisses and the newer granites. The highly calciferous limestones show distinct signs of stratifications and bedding. The thin patches of schists scattered about in the gneissic complex show evidences of repeated metamorphism. A major portion of the district is covered by this complex of granitic gneisses which are classed 
The main rock types occurring in Kolar district are: 1 under a separate group named the peninsular gneiss. The four major components are (i) banded gneisses. (ii) granitic gneisses. (iii) gneissic granites and granites. and (iv) granodiorites. diorites. inter-action diorites and other varieties.. Dharwar - Dark hornblendic schists. amphibolites; tremolite-actinolite schists; 2.Gneissic complex ᄀopalescent quartz, Dolerite dykes and Fine grained dark grey micaceous gneiss with banded gneiss,gneissic granites; 3. Laterite; 4. The Dharwar schists form the oldest Archaean complex. The Kolar schist belt runs North and South for a distance of $65 \mathrm{kms}$ with maximum width of about 6.5 $\mathrm{kms}$ covering an area of $260 \mathrm{sq} \mathrm{kms}$. The famous Kolar Gold Mines are situated in this schist belt. Numerous dykes of dolerite traverse all the rocks of the schist belt and also granitic complex. These dykes run generally in two directions viz.. North $\neg$ South and East-West. The various types of peninsular gneisses and basic dykes serve as good building and decorative stones.

The Chitradurga district is largely composed of crystalline schists, granitic gneisses and the newer granites with a few later intrusive basic dykes. all belonging to the oldest rock formations recognized in India. The schists and their associated rocks constitute, a portion of the Dharwar system and are designated as the Chitradurga and the Chiknayakanahalli schist belt. The schist belts in the district forms a part of thq Dambal-Chiknayakanalli band of Dharwar schists. The occurrence of asbestos is seen near Hosadurga taluk near Budihal and Ganjigere also, in the East of Holalkere. Kudinirakatte and Sunkalhatti.

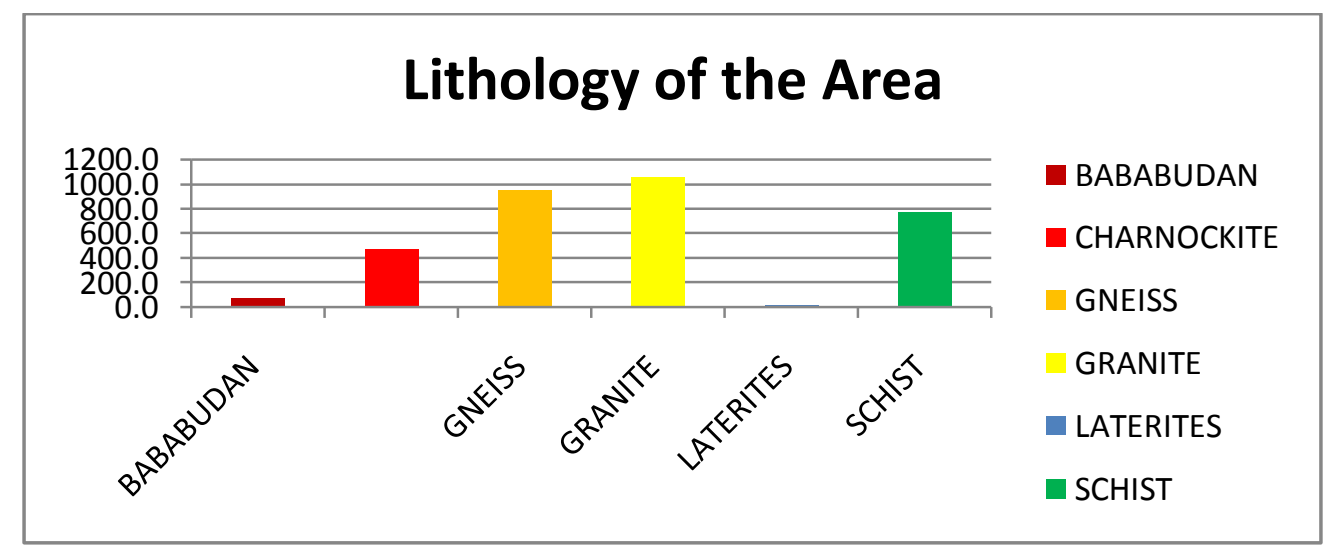

Graph 1.1:- Lithology of the area.

Table 1.1:- Lithology Table.

\begin{tabular}{|l|r|}
\hline Lithology & Area in Sqkms \\
\hline BABABUDAN & 72.0 \\
\hline CHARNOCKITE & 470.8 \\
\hline GNEISS & 950.4 \\
\hline GRANITE & 1062.0 \\
\hline LATERITES & 20.8 \\
\hline SCHIST & 773.0 \\
\hline Total & 3348.9 \\
\hline
\end{tabular}

\section{Acknowledgment:-}

Authors are thankful to the Karnataka State Remote Sensing Application Centre (KSASAC) for producing the satellite data for the study area. Author acknowledges the financial assistance under Rajiv Gandhi National Fellowship (RGNF) 2011-15.

\section{References:-}

1. Drury et al., 1984 S.A. Drury, N.B. Harris, R.W. Holt, G.J. Reeves-Smith, R.T. Wightman Precambrian tectonics and crustal evolution in South India Journal of Geology, 92 (1984), pp. 3-20.

2. Ellison, D., N Futter, M., \& Bishop, K. (2012). On the forest cover-water yield debate: from demand-to supply-side thinking. Global Change Biology,18(3), 806-820.

3. FSI (2002) The manual of instructions for field inventory 2002. Forest Survey of India, Ministry of Environment and Forests, Government of India, Dehradun. 
4. FSI (2011) State of forest report 2011. Forest survey of India, Ministry of environment and forests, government of India, Dehradun.

5. Jayananda et al., 2000 M. Jayananda, J.F. Moyen, H. Martin, J.-J. Peucat, B. Auvray, B. Mahabaleswar Late Archaean (2550-2520 Ma) juvenile magmatism in the Eastern Dharwar craton, southern India: constraints from geochronology, Nd-Sr isotopes and whole rock geochemistry Precambrian Research, 99 (2000), pp. 225-254.

6. Late Archaean, K-rich granitoids, consisting of $\mathrm{N}-\mathrm{S}$ elongate bodies, among which the Closepet granite is the most spectacular. Several of these granites have been dated in the range 2.5-2.6 Ga (Crawford, 1969, Krogstad et al., 1991, Nutman et al., 1996 and Jayananda et al., 2000).

7. M. Jayananda, B. Mahabaleswar Relationships between shear zones and igneous activity: the Closepet granite of Southern India Proceedings of the Indian Academy of Sciences, 100 (1991), pp. 31-36.

8. Mahabaleswar et al., 1995 B. Mahabaleswar, M. Jayananda, J.-J. Peucat, N. Shadakshara Swamy Archaean high-grade gneiss complex from Satnur-Halagur-Sivasamudram area, Karanataka, Southern India: petrogenesis and crustal evolution Journal of the Geological Society of India, 45 (1995), pp. 33-49. 